\title{
Foreignisation of Proper Nouns in Babad Wedyadiningratan Translations
}

\author{
Farah Nur Afini \\ Applied Linguistics Department \\ Yogyakarta State University \\ Yogyakarta, Indonesia \\ farahnurafini94@gmail.com
}

\author{
Sufriati Tanjung \\ Applied Linguistics Department \\ Yogyakarta State University \\ Yogyakarta, Indonesia \\ sufriati@uny.ac.id
}

\begin{abstract}
Foreignisation in translating proper nouns constitutes translators' tendency toward the source language (SL). The tendency based on foreignisation ideology is commonly merged in translation. Yet, in detailed-investigation, it is showed that proper nouns are translated by implementing various translation procedures. In line with that, proper nouns translation in foreignisation ideology gets fascinating to delve. Furthermore, regarded to the cultural relativity of the source language (SL) and the target language (TL), the use of various procedures in translation representing foreignisation ideology illustrated the openness of TL. Therefore, this study is essential to conducted. This study was qualitative descriptive. Translational identity method adapting Sudaryanto's model [1] was used to analyze the data collected. The aim of this study was to describe proper nouns translation analysis in Javanese literature entitled Babad Wedyadiningratan. The analysis consisted of the categorization of proper nouns adapting Paik's model [2], translational procedures adapting Vinay and Darbelnet's model [3] and Newmark's model [4], as well as the portion of the translation procedures used in Babad Wedyadiningratan translation. The analyzed data exhibited that there were 8 from 9 proper nouns categories of Paik's model [2] in Babad Wedyadiningratan; geographic entity, affiliation, organization, human, document, scientific, temporal, and miscellaneous. Borrowing (dominated), calque, literal translation, additional explanation, couplets, and naturalization were proper nouns translation procedures from Vinay and Darbelnet's model [3] and Newmark's model [4] found. According to the data analyzed, the fundamental finding of this study is that the foreignisation ideology related to the language and cultural relativity in proper nouns translation in Babad Wedyadiningratan proves that character of Indonesian as the TL is tolerant to accept Javanese as the $\mathrm{SL}$ which is so close to the cultural feature.
\end{abstract}

Keywords-foreignisation; proper nouns; Babad Wedyadiningratan; translation

\section{INTRODUCTION}

Proper nouns is one of the categories of cultural terms in the form of local institution, road, historical figure, place name (toponym), personal name (anthroponym), and so on [5]. In translation studies, proper nouns frequently become problems for translators relating to the language and cultural relativity. The relativity of language and culture reflect the difference of each society's knowledge background on the basis of its conceptual scheme [6]. Therefore in proper nouns translations the translators who indeed have different conceptual schemes will end up using different ways in translating a text. The method used to solve these problems in relation to the difference of language and culture is a translation procedure based on the tendency towards SL or TL.Venuti [7] states that a tendency or ideology which oriented to SL is called foreignisation and the one which oriented to TL is called domestication.

One of translation problems in translating proper nouns were found in the text of Babad Wedyadiningratan (Javanese) translated into Indonesian. In the translation, the text shows that the proper nouns tend to be translated based on the ideology of foreignisation by the translator. Nevertheless, the translation procedures used varied greatly, thus it needed a further investigation. This was conducted to find out the variation form of the use of proper nouns translation procedure SL and its implications to TL. How the translation of proper nouns in the translated text of Babad Wedyadiningratan represents the ideology of foreignization and shows the character of TL related to the purpose of communication in translation.

\section{LITERATURE REVIEW}

\section{A. Translation, Language, and Culture}

Translation is defined as the process of transferring a written text from SL to TL, conducted by a translator, or translators, in a specific socio-cultural context [8]. It means that translation involves language, translator, and sociocultural context (culture). The involvement of language in translation is based on the relativity of language which in its theory is said that every language is structurally unique [9]. Each language has unique and distinct characteristics from one another, especially structurally, which makes variation of language along with cultural variations inherent in it. Culture covers all aspects of human life [10] so that using language is certainly a representation of cultural values adopted [9]. Because of the problem of language and cultural variations called as language and cultural relativity, it ultimately encourages the presence of translation studies as a bridge for interlanguage communication.

Obstacle related to language and cultural relativity in translation process is always faced by translators. Nevertheless 
the translators overcome it with various translation procedures based on the their ideology. Ideology is generally defined as a principle believed to be true by a particular community in a society [11]. The translator's ideology means the principle / tendency of the translator used as a benchmark for viewing qualified or unqualified quality translation for the readers in accordance with the assumed beliefs. In this ideology of translation, Venuti [7] states that there are two categories of opposite but interrelated ideology that affect translation i.e. SL-oriented ideology (foreignisation) and which orientates to the TL (domestication). The foreignisation ideology is used in translation to make the SL visible and appear as a translation presenting the SL culture. Based on these two ideologies, translation procedures that can be applied to translation process [3], [4] include 1) Borrowing (translation procedure by picking up SL word or term into TL), (2) Calque (literal translation or loan translation for general collocation), 3) Literal translation (adjustment of SL structure in the TL and matching context-free), 4) Transposition (changing one level of language to another level of language), 5) Modulation (translation procedure by changing the point of view or way of thinking), 6) Equivalence (modifying SL word with the equivalent word in TL), 7) Adaptation (translation procedure if the concept in SL is not found in TL then replaced with TL concept), 8) Generic word (translation procedure with generic word used to overcome the difficulty of finding the more specific word in TL), 9) Additional explanation (translation procedure if there is a word which is unfamiliar to TL text reader), 10) Couplet / triplet / quadruplet (when there are more than one procedure used by the translator in translating a word / phrase from SL to TL), 11) Naturalisation (a procedure adapting word of SL to become TL word that has natural pronunciation and morphological structure in SL).

\section{B. Proper Nouns}

Proper nouns is a term which is considered more appropriate to refer to object, institution, custom, and opinion limited to certain culture that can not be included in the proper names class [5]. In translation, proper nouns are difficult to translate [12] even can never be translated [13]. Proper nouns contain referential indexes and although they do not have a distinctive identity, proper nouns show identification of the common noun associated with them [14]. For example Rajiman and all other names indicate identity criteria of person.

Proper nouns are classified into 9 categories [2] those are 1) Geographic entity (city, port, airport, island, country, province, county, continent, region, water, geographic miscellaneous), 2) Affiliation (religion, nationality), 3) Organization (company, company type, goverment, U. S. Gov., organization), 4) Human (person tittle), 5) Document (document), 6) Scientific (disease, drugs, chemicals), 7) Temporal (date, time), 8) Equipment (software, hardware, machines), and 9) Miscellaneous (miscellaneous).

\section{Babad Wedyadiningratan}

Babad is a classical Javanese literary work which contains historical content [15]. Babad is written in Javanese script and language which is usually translated into Indonesian. Based on its contents of the text, the literature of babad can be divided into 3 [15] those are 1) Babad that contains the history of a place like Babad Tanah Jawi, 2) Babad which contains the history of a figure's struggle such as Babad Ajisaka, 3) Babad that contains an event such as Babad Giyanti. Based on these explanations, Babad Wedyadiningratan included in a kind of chronicle which tells the history of one's struggle i.e. doctor Wedyadiningrat, one of the founders of Budi Utomo organization who participated in the struggle of independence of Republic Indonesia through his devotion to the palace, society, and state.

\section{RESEARCH DESIGN}

\section{A. Objectives of the Research Questions}

The aims of this study were 1) to identify the category of proper nouns which were translated based on the ideology of foreignisation on the text of Babad Wedyadiningratan, and 2) to find out the variation of translation procedures. This is intended to confirm the diversity of proper nouns and the use of translation procedures that represented the ideology of foreignisation indicate character of TL toward the element of the incoming foreign language.

\section{B. Data Resources}

The source of this research were a document in the form of translational text of Javanese-Indonesian language entitled Babad Wedyadningratan and dictionary (Bausastra Jawa and Indonesian dictionary) as supporting document of proper nouns translation research.

\section{Data Analysis}

The analysis of research data begun with data collection process. Then, the data were analyzed using translational identity method that used another language to identify the language unit of the language under study [1]. This method facilitates the collection of proper nouns data, the classification, and analysis of translation procedures used in the proper nouns translation.

\section{ANALYSIS OF FINDINGS}

Based on the analysis that has been conducted for the first step, there are 582 proper nouns that have been translated which refer to foreignisation within the text of Babad Wedyadiningratan. All of those proper nouns then are classified into several categories according to Paik's model [2]. Moreover, translation procedure of proper nouns which have been classified are also identified in order to know how those procedures represent the ideology of fereignisation which relevant to the collaboration of classification according to Vinay and Darbelnet' [3] model and Newmark's model [4] in Babad Wedyadiningratan. Here are the results of the analysis of proper nouns in that translated text.

\section{A. Proper Nouns Classification in Babad Wedyadiningratan}

There are 8 out of 9 categories which are found and translated based on the fereignisation ideology in the text Babad Wedyadiningratan. those are: 
1) Geographic entity: There are 125 geographic entities in the text, several of them are name of place (Wedyadiningratan), name of hamlet (Dhusun Mlathi), name of village (Kampung Lempuyangan), name of regency (Kabupaten Panumping), name of regional district (Manado, Klaten), name of certain area in overseas (Eropa, Berlin), name of area which inhabitate by certain etnicity (Pacinan), geographic name (Redi Tengger), name of realm area (Surakarta Adiningrat).

2) Affiliation: there are 41 affiliation found in the text which related to religion (Hyang Rudra, Hyang Wisesa) and nationality (Indonesia, Jepang).

3) Organization: 36 proper nouns of organozation are found and the most frequently occur are Biwaddha Mulya (7 times), Budi Utama (10 times), and Wedha Sanjaya (2 times).

4) Human: there a re 337 proper noun of human such as title of govermental degre (Pepatih, Kliwon), and personal name (Dokter Rajiman, Dokter K. R. T. Wedyadiningrat).

5) Document: there are 22 proper nouns of document in the text. Those are Serat Arjuna Wiwaha (4 times), Kakawin, and Babad Wedyadiningratan.

6) Scientific: 5 scientific proper nouns are found in the text. Two of them are Philosofie and Okultis.

7) Temporal: temporal category of proper noun in the text are mentioned 11 times such as name of days (Kemis Pahing), name of month (jumadil awal), name of year (Warsa Be), name of age (Jaman Mataram), and name of wuku (Wuku Mandhasiya).

8) Miscellaneous:Miscellaneous proper nouns are found in the text as 5, namely Bintang Sri Kabadya (2 times) and Sekar Ageng.

\section{B. Translation Procedure of Proper Nouns in Babad Wedyadiningratan}

Here are the translation procedures of proper nouns based on foreignisation ideology which are used in the Babad Wedyadiningratan translation according to Vinay and Darbelnet's model [3] and Newmark's model [4].

1) Borrowing: this procedure is found in 377 translation of proper nouns. In this procedure, the translator brought all the components of SL into the TL entirely. For example:

$\mathrm{SL}=$ Babad Wedyadiningratan and Biwaddha Mulya

$\mathrm{TL}=$ Babad Wedyadiningratan and Biwaddha Mulya

2) Calque: Calque is applied to translate 122 proper nouns. This procedure allows the preoper nouns to have the spelling as in the TL, however still have the same nuance of SL because having an adjusment on several phonem. For example:

$S L=$ Kemis Pahing and Wuku Mandhasiya

$T L=$ Kamis Pahing and Wuku Mandasiya

From those two proper nouns, the changes occur in the vowel $e$ bocomes $a$ (Kemis=Kamis) and the elipsis of $h$ (Mandhasiya = Mandasiya).

3) Literal Translation: This procedure is only presented in 14 proper nouns in the text. One of them is:

$S L=$ Serat Harjuna Sasrabau

\section{$T L=$ Kitab Arjuna Sasrabau}

Based on that translation, it can be said that literal translation is an adaptation of TL structure into SL structure although there is a word replacment and phonem adaptation into TL. Serat Harjuna Sasrabau is indeed translated into Kitab Arjuna Sasrabau by replacing the word Serat by Kitab and deleting the letter $h$ in order to gain the attachment into the TL. However, the TL's structure still refer to the SL's therefore the tendency into SL remains to be strong.

4) Additional explanation: 14 proper nouns in the text are translated using this procedure. For example:

$\mathrm{SL}=$ Mataram

$\mathrm{TL}=$ Kerajaan Mataram

Based on that procedure it could be said that the purpose is to make clearance of the translated text. Nevertheless, the involvement of SL's elements is still there in order to strengthen the foreign culture (SL culture) toward TL and the reader.

5) Couplets: there are 7 proper nouns which is translated by using couplet in its translation. One of them is:

SL = Kliwon

$\mathrm{TL}=$ Kliwon (kurang lebih sama dengan wedana)

From that translation it can be known that couplet is a variation and combination from the existing procedures. In this case, the proper noun Kliwon is translated by using couplet which combines borrowing and additional explanation.

6) Naturalisation:This procedure is found in 48 pproper nouns. In subing this procedure, the translator adjusts the SL's spelling into TL's. It is like borrowing, however this procedure changes the phonem of the word in order to meet the TL's spelling. For example:

$\mathrm{SL}=$ Berlijn

$\mathrm{TL}=$ Berlin

From that translation, the change is only occur in certain phonem namely the consonat $j$ in the word Berlijn. It is elipted in order to meet the TL's spelling Berlin.

Resuming all the application pf the translation procedures of proper nouns in Babad Wedyadiningratan, here the results can be seen through the preseted table 1 below.

TABLE I. The Use of Translation Procedure of Proper NoUnS IN BABAD WEDYADININGRATAN

\begin{tabular}{|l|c|}
\hline \multicolumn{1}{|c|}{$\begin{array}{c}\text { The Use of Translation Procedure of Proper Nouns in Babad } \\
\text { Wedyadiningratan }\end{array}$} \\
\hline Borrowing & Frequency \\
\hline Calque & $65 \%$ \\
\hline Literal Translation & $21 \%$ \\
\hline Additional Explanation & $2 \%$ \\
\hline Couplets & $2 \%$ \\
\hline Naturalisation & $1 \%$ \\
\hline
\end{tabular}


This table shows the use of translation procedure of proper nouns in Babad Wedyadiningratan. borrowing is the most frequently used procedure as it has $65 \%$ usage. The second is calque for $21 \%$. Then, naturalization is $9 \%$. The same number goes to literal translation and additional translation for $2 \%$; and the last is couplet for $1 \%$. It means that within the realm of foreignisation ideology, the translator of Babad Wdyadiningratan tends to use borroeing that transfer the SL into TL fully and entirely to present the strong SL culture nuance, thus the SL becomes visible.

\section{CONCLUSION}

In the proper noun translation case, especially in the text of Babad Wedyadiningratan, it can be scrutinized into 8 out of 9 categories according to Paik's model [2]. It shows that the proper nouns are quite varied. Furthermore, those proper nouns are also translated using 6 translation procedures which refer to SL [3], [4]. In other word, the use of this procedures representing the foreignisation ideologywhich nelieved to be good and right by the translator to translate Babad Wedyadiningratan. The fact of the tendency toward the ideology of foreignisation not only about how good or bad the translation is. However, it can be seen through another point of view, the translation which is dominated by the ideology of $\mathrm{SL}$ (foreignisation) uncover the veil that the truth is that TL has open characteristics toward foreign input which probably will give exotic nuance in the translation. In this case, Babad Wedyadiningratan which is written in Javanesse language (SL) that is translated into Indonesian language (TL) is an evidence that Indonesian language is an tolerant language toward foreign elements. Therefore, Indonesian people who are not mostly communicate by using Javanesse language will understand several Javanesse terms which usually occurs in daily communication using Indonesian language such as in the text of Babad Wedyadiningratan.

\section{ACKNOWLEDGMENT}

I am especially grateful for Dr. Sufriati Tanjung, M. Pd. and those who gave warm support, inspiration, and thoughtful guidance in finishing this research.

\section{REFERENCES}

[1] Sudaryanto, Metode dan Aneka Teknik Analisis Bahasa [Methods and Various Techniques of Language Analysis]. Yogyakarta: Sanata Dharma University Press, 2015.

[2] W. Paik, E. D. Liddy, E. Yu, and M. Mckenna, "Categorizing And Standardizing Proper Nouns for Efficient Information Retrieval," Acquis. Lex. Knowl. from Text, pp. 154-160, 1993.

[3] J. Munday, Introducing Translation Studies. Theories and Applications, Second., vol. 2. London and New York: Routledge, 2008.

[4] P. Newmark, A Textbook of Translation. Tokyo, New York, London, Toronto, and Sydney: Prentice HaH International vUIO Ltd., 1988.

[5] J. F. Aixélâ, Translation, Power, Subversion : Culture-specific Items in Translation, 8th ed. England: Multilingual Matters Ltd., 1996.

[6] W. A. Foley, “Anthropological Linguistics: An Introduction,” Lang. in Soci., vol. 24., p. 495, 1997.

[7] L. Venuti, The Translator's Invisibility: A History of Translation, 2nd ed. USA and Canada: Routledge, 1995.

[8] B. Hatim and J. Munday, Translation An Advanced Resource Book, vol. 53, no. 9. London and New York: Routledge, 2004

[9] A. E. Kadarisman, "Relativitas Bahasa dan Relativitas Budaya [Language and Culture Relativity],” Lingu. Indo. J., Malang, p. 20, 2005.

[10] T. O. Ihromi, Pokok-pokok Antropologi Budaya [Cultural Anthropology's Principals], 1st ed. Jakarta: Yayasan Pustaka Obor Indonesia, 1980

[11] B. H. Hoed, "Ideologi dalam Penerjemahan [Ideology in Translation]," Kongr. Nas. Penerjemahan, p. 14, 2003.

[12] P. Newmark, Paragraphs On Translation Topics in Translation. England: Multilingual Matters Ltd, 1993.

[13] C. Nord, "Proper Names in Translations for Children,” Meta J. des traducteurs, vol. 48, no. 1-2, p. 182, 2003

[14] M. C. Baker, Lexical Categories: Verbs, Nouns, and Adjectives. United Kingdom: Cambridge University Press, 2004

[15] M. W. Hendrosaputro, Ensiklopedi Kebudayaan Jawa [Javanese Cultural Encyclopedia]. Yogyakarta: Yayasan Studi Jawa, Lembaga Studi Jawa, 1999. 